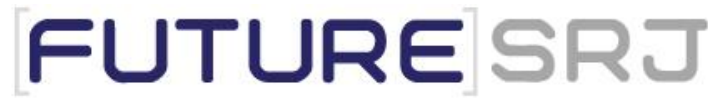

FUTURE STUDIES RESEARCH JOURNAL: TRENDS AND STRATEGIES
Profuturo: future Studies Program

Scientific Editor: James Terence Coulter Wright

Evaluation: Double Blind Review, pelo SEER/OJS

Review: Grammatical, normative and layout

Received in: 08/29/2014 Approved in: 10/07/2014

THE IMPACT OF THE STADIUM IN THE SUPPORTER'S CONSUMPTION:

HOW DOES THE FREQUENCY AT THE STADIUM BOOSTS THE DEMAND FOR THE CLUBS' PRODUCTS

Fernando A. Fleury

Doctorate Student in Business Administration in Economics of Organizations at the University of São Paulo, Brazil

fleury00@gmail.com

Marcos Vinícius Cardoso

PhD in Business Administration by the University of São Paulo, Brazil mvcardoso@gmail.com

Nuno Dias Fouto

PhD in Business Administration by the University of São Paulo, Brazil nunom@fia.com.br

Patrícia Vance

PhD in Business Administration by the University of São Paulo, Brazil patricia.vance@gmail.com

Rui Marques

Master in Business Administration with emphasis Sports Management by the Nove de Julho University, Brazil

ruimarquess@gmail.com

\title{
ABSTRACT
}

The aim of this study is to investigate the relationship between the presence of supporter in the stadium, which demonstrates the supporter's involvement with his soccer club, and its influence on the purchase of official products of the 12 largest Brazilian brands of soccer clubs. In this research, it was collected information from 1,296 supporters who responded to a questionnaire with 22 questions. It was defined as involvement with their soccer club the frequency this supporter goes to the stadium. In order to determine the consumption relationship it were used variables such as frequency of purchase of 
Profuturo: future Studies Program

Scientific Editor: James Terence Coulter Wright

Evaluation: Double Blind Review, pelo SEER/OJS

Review: Grammatical, normative and layout

Received in: 08/29/2014 Approved in: 10/07/2014

official products, the annual amount spent on such products, favorite venue to purchase and assortment of the products mix. For the supporters buying preferences analysis, it was applied the technique of correspondence analysis (Anacor). As a result, we can point out that the supporters' loyalty, driven by the relationship marketing, is one of the catalysts for increasing the soccer clubs revenue, since the higher the products and average tickets purchase frequency, the more this frequency is associated with a higher number of attendance to the stadium, as well as the variety in the mix of products acquired by the supporter. In this sense, the work points to the importance of building a long term relationship which goes beyond the emotional bond with the club, reaching the brand products consumption.

KEYWORDS: Sports Marketing. Relationship marketing. Brand loyalty. Soccer Clubs. Soccer clubs loyalty.

\section{O IMPACTO DO ESTÁDIO NO CONSUMO DO TORCEDOR: COMO A FREQUÊNCIA NO ESTÁDIO IMPULSIONA A DEMANDA POR PRODUTOS DOS CLUBES}

\section{RESUMO}

O objetivo deste estudo é investigar a relação existente entre a presença do torcedor no estádio, que demonstra o envolvimento do torcedor com seu clube de futebol, e sua influência na compra de produtos oficiais das 12 maiores marcas brasileiras de clubes de futebol. Nesta pesquisa, coletaram-se informações de 1.296 torcedores que responderam a um questionário com 22 perguntas. Definiu-se como envolvimento com seu clube de futebol a frequência de ida ao estádio. Para determinar a relação de consumo, foram utilizadas variáveis como frequência de compra de produtos oficiais, valor anual gasto com tais produtos, local preferido 
Profuturo: future Studies Program

Scientific Editor: James Terence Coulter Wright

Evaluation: Double Blind Review, pelo SEER/OJS

Review: Grammatical, normative and layout

Received in: 08/29/2014 Approved in: 10/07/2014

para realização de compras e sortimento do mix de produto. Para a análise das preferências de compra do torcedor, foi aplicada a técnica de análise de correspondência (Anacor). Como resultado, pode-se apontar que a fidelização do torcedor, impulsionada pelo marketing de relacionamento, é um dos catalisadores para aumentar as receitas dos clubes de futebol, já que maiores frequências de compra e tíquetes médios estão associadas a um número maior de idas ao estádio, assim como à variedade do mix de produtos adquiridos pelo torcedor. Nesse sentido, o trabalho aponta para a importância de construir uma relação de longo prazo que vá além do vínculo emocional com o clube, chegando até ao consumo dos produtos da marca.

PALAVRAS-CHAVE: Marketing esportivo. Marketing de relacionamento.

Fidelidade à marca. Clubes de Futebol. Fidelidade a clubes de futebol. 


\section{INTRODUCTION}

The sports industry in Brazil generates around $\mathrm{R} \$ 67$ billion annually, which corresponds to $1.6 \%$ of the GDP and the sporting goods segment generates nearly R\$ 4 billion annually (Pluri, 2012). The sports industry has been internationally investigated with great intensity, in the most varied aspects (Wert-Gray \& Gray, 2012), but it is a relatively unexplored theme on the national scenario (Malagrino, 2011). With the country's economic growth and the expansion of the middle class, the proper management of this segment can become an important source of revenue for clubs (Chao, 2013).

In this setting, the supporter plays a dual role. At the same time that he is the target audience of the sponsors' actions and of the club itself, he also enhances the performance, when increasing the consumption of products and services linked to the club, and boost the growth of its revenue. Thus, the supporter will only become a source of revenue for his club when this club establishes a close relationship with him, enabling him to experience unique and unforgettable moments with the club (Gladden \& Funk, 2001).

To make it happen it is necessary that clubs are aware about who their consumers are, how these consumers think and what they seek. Currently, a number of soccer clubs have already established networks of franchised stores that trade exclusively official and licensed products. The rapid growth of franchised stores of two of the most valuable clubs in terms of brand equity in Brazil, Corinthians and São Paulo, illustrates the importance of understanding in practice the soccer consumer habits (Malagrino, Vance, Cardoso \& Silva, 2012; Chao, 2013).

The literature review aimed to present the latest theories about the sports consumer loyalty, in order to understand the importance of the supporter loyalty for the success of the sports brands. According to Tokuyama and Greenwell (2011), sports supporters and practitioners tend to have different consumption habits, therefore identifying what shapes the soccer supporter becomes important in the customer loyalty process. This loyalty can be influenced by relationship marketing actions, generating, as a result, higher frequency of official products buying, higher average ticket and also brand internationalization 
(Kaynak, Salman \& Tatoglu, 2008). This customer loyalty, however, is subject to the same restrictions imposed on brands considered as strong brands on the market (Ehrenberg, 2000), as there is a competition of both, international clubs and other companies considered by consumers (supporters) at the time of purchase.

In this study, it is sought to investigate "what is the relationship between customer loyalty (going to the stadium) and the average ticket of consumer spending - specifically called "supporters"- and the purchase frequency of official products of the clubs related to the 12 most valuable brands of the soccer market - (Atlético-MG, Botafogo, Corinthians, Cruzeiro, Flamengo, Fluminense, Gremio, Internacional, Palmeiras, Santos, São Paulo and Vasco da Gama). The brands were chosen using the data collected by the auditors of BDO (2012).

This engagement involves understanding, even before the consumption habits, the supporters' willingness to get involved with the team, for example, their frequency of going to the stadium and what his favorite venue to watch a soccer match is. It is assumed that, at this time, the emotional involvement and their identification with the team influence the supporter purchasing frequency and may facilitate the establishment of a long term relationship, broadening the loyalty process, as pointed out by Gray and Gray-Wert (2012). To identify this involvement, the path chosen was a survey research in order to gather information about the soccer supporter and the application of the correspondence analysis technique (Anacor) in order to verify the association between the variables studied in the survey, analyzing both the contingency table as well as the perceptual map, having as proxy the frequency of going to the soccer stadium.

It was clear in this study that, according to Gladden and Funk (2002), the presence in the stadium has a direct association with the purchasing frequency and the amount spent annually by the supporter. This presence also influences the purchased mix of products. Thus, the more loyal the supporter is towards his club, the closer is the relationship between the parts of the study and, according to Wert-Gray and Gray (2012), the impact on consumption tends to happen after the setting up of identification between club and supporter.

Despite being expected a higher fidelity towards brands of his favorite team, it is important to emphasize that the income restrictions must also be 
considered. The general idea that the supporter is a loyal customer and that the club does not need to strengthen its relationship with him can result in decisionmaking that will affect the sales potential of the brands soccer products. In this sense, understanding the differences between frequency, purchase value and location of consumption may help the teams' managers to develop more effective and long lasting marketing strategies.

The paper is structured into five parts, with this introduction. The second part presents a literature review on the soccer consumer loyalty and the relationship marketing in the sport industry. The third part describes the methodology used to collect and analyze the data and also the sample profile. The fourth part presents the study results. The article ends presenting the discussions on the results, the final considerations and suggestions for future researches.

\section{LITERATURE REVIEW}

\subsection{LOYALTY OF THE SOCCER CLUB BRANDS' CONSUMER}

Virtually every country throughout the world has its favorite sport and the followers of these sports activities can be considered a target market for the consumption of products of several clubs in different modalities. In Brazil, soccer is the major sports reference and has become one of the great passions of Brazilian people.

Studies have shown that there are differences in the consumption behavior of products related to teams among people who watch sports, usually called supporters, and those who are sports enthusiast. Stone (1971) has already pointed out such a difference when analyzing the predecessor and consequent variables of each activity (to support and to practice sports). As the variables were different for each activity, the author concludes that support and practice sports are activities of distinct nature. Shamir and Ruskin (1984) have examined the motivations that lie behind supporting and practicing sports. Some reasons such as ability and health were the most important for the sports practice. Social 
experience and aesthetic experience were the most important factors to watch the games and support a club.

Tokuyama and Greenwell (2011) work on the concept of involvement (high and low) with the sport and how it produces different characteristics between those who practice soccer and those who prefer to watch the games and support their clubs. In the group of high involvement, personal fulfillment and stress reduction have been identified as the main factors among those who practice the sport. Among those who prefer to support their clubs and watch the games, the authors pointed out as fundamental factors the opportunity of belonging to a specific community (supporters club) and the competition, in other words, the importance of a strong and intense competition. The final results of these studies show that both the differences and the similarities of the consumption motivators of these two groups can assist the professionals of sports marketing to make decisions about where and how to exhibit their products.

Gladden and Funk (2001) show that the consumer brand loyalty in sports is important for two reasons: First, when the team loses or undergoes consecutive defeats, loyalty to the club (brand) ensures the supporters continuity. Such a loyalty often makes that even in adversity, the presence of supporters in the stadium increases, thus ensuring continuity in the revenue collection. In a moment of crisis, arising from defeats or even a downgrade, such a move is important because it helps to offset a possible increase in costs in other areas salaries of players, for example - to overcome the crisis. This same process ensures that the club will continue to be on the media. Secondly, consumer brand loyalty is essential to the product line extension process. Clubs that hold, not only more supporters, but mainly, supporters more devoted to the brand, have more chances to extend their product offering. This may create additional cash flows on the balance sheets and bring new business partners.

One difficulty observed among the Brazilian soccer clubs to develop their offerings to the supporters is the international competition. According to Kaynak et al. (2008), the result of the high loyalty, or nearly the unconditional loyalty, is the possibility for extending the brand beyond the geographical boundaries. Currently in Brazil there are three major pay Television channels that broadcast international soccer - SporTV, ESPN and Fox Sports - and at least three FTA TV channels (Free-to-air television) doing the same thing - Band, Globo and Rede 
TV. The international brands, brought by the media globalization, help to develop this process and build a phenomenon that is the demand for foreign clubs products, which do not relate to local clubs. What is not seen as an act of infidelity, since the products are not direct competitors of Brazilian clubs. This fact is evidenced in the consumption on virtually all the markets in which major brands do not have unconditional loyalty but instead, higher loyalty (Ehrenberg, 1991; Ehrenberg \& Goodhardt, 2002). In general, the brands share their customers with other brands that hold similar market share (Ehrenberg, 2000). This consumption pattern was analyzed by Dawes (2009) who, when studying consumer brand loyalty in the sportswear market, found that Nike and Adidas, for example, go through the same brands phenomenon in other markets.

This fact begins to occur more frequently with the soccer clubs since the several brand extensions carried out in segments such as clothing and small collector's items such as cups and keyrings, lead clubs to compete with other major brands in the consumer's life. So when selling a polo shirt, clubs such as São Paulo may be competing in terms of brand, with the Polo by Ralph Lauren; similarly, a car's keyring holding Corinthians or Palmeiras logo may be competing with the BMW keyrings or even with Ferrari keyrings. This concept facilitates the understanding that no matter how faithful the soccer consumer is, there are limits of quality and price (Kapferer, 2003), which do not allow excesses often practiced by the soccer clubs. To compete on an equal basis with international clubs, or even with other brands, national clubs need to win the consumer preference by building strong and long-lasting relationships as well as positive beliefs. In other words, national clubs need to build a strong brand name, with a good image for their supporters, increasing the consumers' loyalty beyond the pitch lines (Bauer, Sauer \& Stokburger Exler, 2008).

Given this context, it is the necessary to generate more and more relationship between the soccer clubs and their customers so that they consume more products in every interaction with their favorite team. The competitive nature of the sport can help in this process (Bauer et al., 2008). Thus, as suggested by Ross (2006), the theoretical and empirical research can be a good path to understand the relationship between brand and loyalty, and the intersection of this process in the use of relationship marketing, understanding that the ultimate objective is to create long lasting bonds with the supporters. 
Hence, the passion is not the single element that keeps the supporter loyalty to his soccer club.

\subsection{THE INFLUENCE OF RELATIONSHIP MARKETING IN SPORTS}

Despite its widespread use in the sales relations context between suppliers and buyers, between retailers and suppliers, in service relations, in brand relations, and also in the relations between consumer and company, few studies have been conducted about relationship marketing in sports (Bee \& Kahle, 2006). But the theme - over the past two decades - has conquered more room, especially in the international scenario (Wert-Gray \& Gray, 2012). This is so because several reasons have favored the relationship marketing development in the sports universe, such as technological innovations, improvements in the marketing research models, and especially the sport has been assuming its role as entertainment activity (Stavros, Winzar \& Pope, 2008).

Relationship marketing can be characterized by the attraction, development and consumers' retention (Bee \& Kahle, 2006). However, there are two ways of understanding these characteristics. On one hand, relationship marketing has a transactional component that seeks to increase sales; on the other there is a focus in the long-term relationship (Parvatiyar \& Sheth, 2001). While in the first case, one can use methods more focused on database marketing, in order to generate more buying and larger average ticket, in the second the aim is to reach a long-term relationship, less transactional and more relational, after all, the soccer club emphasizes cooperation and interaction, resulting in shared values (Bee \& Kahle, 2006).

The long-term relationship with a brand has benefits for consumers (Parvatiyar \& Sheth, 2001). These benefits are based on the preference for reducing the choices, since the decision making process turns to be more efficient, the search costs fall and the cognitive decision consistency can rise. To Bee and Kahle (2006) the sports' consumer is usually deeply involved and such involvement can be seen through the purchase tickets and products related to his team. This fact is confirmed by the desire to demonstrate his involvement and keeping a closer relationship with his club. The authors argue that the 
confidence, either on the team, players or staff, and the shared values strongly influence the consumer relationship.

Bee and Kahle (2006) further submit that there are at least three common techniques to make the relationship between clubs and consumers grow. The first is the "Sports Talk", since the mere fact of the interaction on the topic sport or club can establish shared values. The second technique is the "hospitality", which in Brazil is related to the stadium and other means through which supporters (consumers) can socially interact creating the possibility for the "Sports Talk" as well as the sharing of values. And the third technique, less common in Brazil, is the act of "offering giveaways".

There are several types of consumer rewards programs that require promised and provided reinforcements; the consumer can be persistently conditioned over long periods of time, as a result of receiving rewards (Sheth \& Parvatiyar, 1995; Bendapudi \& Berry, 1997). The Benefit clubs (points, bonuses, gifts, coupons) are examples of such efforts that keep the consumers' loyalty, regardless of promotion or improvement of the competitors' services (Stum \& Thiry, 1991; O'Brien \& Jones, 1995).

Wulf and Odekerken-Schroder (2003) suggest that the relationship efforts can be perceived only after ongoing exchanges between retailers (in this case, soccer clubs) and their consumers. Many of the relationship costs and benefits are not assessed in the relationship early stages. For this reason it is important to work on a long-term relationship. For the authors, the commitment in the relationship becomes a variable which measures the attitudinal component of loyalty, that is, attitudes influence behavior. Considering that the authors define relationship commitment as the consumer's desire to continue a relationship with a retailer along with the retailer's willingness to make efforts to keep him, the authors assume that there is a positive relationship between the relationship commitment and the behavioral loyalty.

To better understand the relationship level, Bee and Kahle (2006) identified that the consumer must go through three stages: observance, identification and internalization. In the first stage, there is a very weak relationship, since there is little involvement with the club brand. In the identification stage, it is expected more consumption, due to the larger relationship between the sports organization and the consumer. And lastly, in the internalization stage, consumer 
values are the same as those of the club, either by going through the whole process or for the recognition of these values.

Then it is observed that, when values are shared, consumers tend to follow their club more closely, looking for information about it, regardless of its position in the championship or any negative results. In this last phase, the consumption loyalty is very near the consumer and being so he starts spending part of his income going to the stadium more frequently in order to watch the soccer matches instead of other ways of entertainment. To make it happen, it is also necessary the identification with the club. Wert-Gray and Gray (2012) suggest that in order to obtain greater impact on consumption behavior, it is necessary to establish strong identification between the club and the supporter. The authors also suggest that "the continuous efforts of a sports organization to establish a relationship with their supporters may provide benefits greater than the efforts to improve the team competitive performance" (Wert-Gray and Gray, 2012, p. 277).

In improving the relationship between club and supporter, the soccer clubs should beware of the sport peculiarity, highlighted by Malagrino (2011), referring to the notion that the supporter goes beyond collaborating with the club. Very often, he becomes part of the own show that he himself creates, for "it is him who, uniformed and characterized as a supporter, with his banners, flags and honking horns, crams the stadium stands, producing an image capable of further enhance the value of the final product: the match"(Malagrino, 2011, p. 39).

\section{METHODOLOGY}

The sample searched included 1,296 supporters of Brazilian soccer teams. Non-probability sampling techniques were adopted, mainly due to the interest in focusing the research on supporters of the 12 clubs with the most valuable brands in Brazil (Atletico-MG, Botafogo, Corinthians, Cruzeiro, Flamengo, Fluminense, Gremio, Internacional, Palmeiras, Santos, São Paulo and Vasco da Gama), using as reference the work of the consultancy BDO (2012). The sample universe was bounded through two distinct types of non-probability sample: for convenience (convenience) - participants are chosen because they are available and snowball (snowball) - initial participants indicate new participants (Freitas 
Oliveira, Saccol \& Mascarola, 2000). From the total of 1,296 respondents, 95 supporters ( $7.3 \%$ of the total) were excluded from the final analysis because they responded they were other clubs' supporters or because they responded that they were not passionate about any soccer club, remaining 1,201 valid respondents, of which 991 male supporters (82.5\%) and 210 female supporters $(17.5 \%)$.

For the attainment of this paper it was used the number of visits to the stadium as a variable that can show the internalization process, since going to the stadium, regardless of the situation, positive or negative, of his club, can demonstrate the sharing of values. Thus, it can be analyzed, although in a rough way, what the expected results are, in terms of sales, when the consumer goes to the stadium more frequently compared to those who are less involved. Thus, the analysis focus was the frequency of going to the stadium - used as the supporter loyalty proxy to the team he supports (Lings \& Owen, 2007). Other variables of analysis include the frequency of buying official products, the annual amount spent on such goods and the favorite venue for shopping.

To analyze the relation between frequency of going to the stadium and purchase frequency, as well as the first (the frequency of going to the stadium) and the average ticket, it was applied the correspondence analysis technique (Anacor) - a technique of interdependence which works in the reduction of dimensions and depicts the results through perceptual maps. The Anacor shows the associations between nominal categorical variables allowing a visual check of a pattern or data structure (Whitlark \& Smith, 2001). The maps enable easy visualization of the associations between variables. The contingency table and the perceptual map were analyzed.

Favero, Belfiore, Chan and Smith (2009) argue that categories located near each other on the map show strong relationship, in contrast to categories separated with greater distances. The use of the correspondence analysis allows analyzing non linear relationships and data with categorical responses, whose measurements are nominal, grouping the highly associated variables. The authors state that the strength of this technique lies in the fact that it provides the means for examining the relationships between variables in row and column together. Using this technique, it was possible to make associations on the 
supporter's (consumer) frequency of going to the stadium, the frequency of his buying official products and the amount spent on the average ticket.

As recommended by Pestana and Gageiro (2000), it was carried out the chisquare $\left(\chi^{2}\right)$ test to verify if there is dependence between the pairs of variables or not, thus defining whether to use the technique or not. Then it was examined the association between pairs of these variables categories through the residual analysis as suggested by Pereira (1997) and Batista, Escuder and Pereira (2004).

\section{RESULTS}

In order to analyze the association of the supporter loyalty (frequency of going to the stadium) with his buying frequency, several aspects were investigated, such as buying frequency, favorite venue for buying, purchased products, the annual amount spent on purchasing official products as well as the attributes of consumer dissatisfaction with the products offered. The first step to understand the soccer supporter loyalty degree is to understand his relationship with the stadium, in other words, how frequently the soccer supporter goes to the stadium, because this frequency can be one of the major financial bases for soccer clubs, besides becoming one of the major distribution channels of the sports industry. At this point, the survey has downplayed the fact that $8.9 \%$ of respondents consider the stadium as their favorite venue to watch their club matches.

Watching the matches at home is still the preference of the significant majority, which explains the variations in the broadcasting rights values negotiated between clubs and TV stations (Betting, 2011). This fact also demonstrates the importance that this type of supporter has for the club and the reason for this revenue be the main source of financial funds for the Brazilian clubs currently (Malagrino et al., 2012), once, despite the importance of the stadium as means of communication, the television media is still the greatest exponent for the majority of Brazilian soccer supporters, allowing easy access and, in most cases, with much more comfort. 


\subsection{FREQUENCY OF GOING TO THE STADIUM AND FREQUENCY OF BUYING OFFICIAL PRODUCTS}

It can be observed through the Table 1 , that when a comparison is made between the frequency of going to the stadium and the frequency of buying, it becomes clear that these variables are not independent $\left(\chi^{2}=348,449 ; p=0,000\right)$, in other words, they are not randomly combined, thus allowing the application of the correspondence analysis technique.

Table 1: Table of comparison between frequency of going to the stadium and frequency of buying official products

\begin{tabular}{ccccccc}
\hline $\begin{array}{c}\text { Frequency of } \\
\text { going to the } \\
\text { stadium }\end{array}$ & Do not buy & Annual & Semester & Quarterly & Monthly & Total \\
\cline { 2 - 6 } $\begin{array}{c}\text { Never goes to } \\
\text { the stadium }\end{array}$ & 157 & 118 & 68 & 22 & 2 & 367 \\
$\begin{array}{c}\text { Once a year } \\
\text { Once a }\end{array}$ & 52 & 91 & 57 & 30 & 2 & 232 \\
$\begin{array}{c}\text { semester } \\
\text { Once a }\end{array}$ & 27 & 45 & 42 & 30 & 5 & 149 \\
quarter & 24 & 42 & 56 & 47 & 7 & 176 \\
$\begin{array}{c}\text { Once a } \\
\text { month }\end{array}$ & 17 & 31 & 63 & 63 & 26 & 200 \\
\hline All matches & 3 & 9 & 17 & 25 & 23 & 77 \\
\hline Total & 280 & 336 & 303 & 217 & 65 & 1201 \\
\hline$\chi^{2}: 348,449$ & GL:20 & p:0,000 & & & \\
\hline
\end{tabular}

Graph 1 analysis points out the existence of an association between the frequency of going to the stadium and the frequency of buying. Thus, the higher is the supporter frequency to the stadiums, the greater is his habit of buying official products. It is clear the association between the most loyal supporters, who go to all matches, and the monthly buying of official products. The proximity of the non purchase with the supporters who do not go to the stadium shows 
that the less faithful the supporter, the lower propensity to consume original products. 


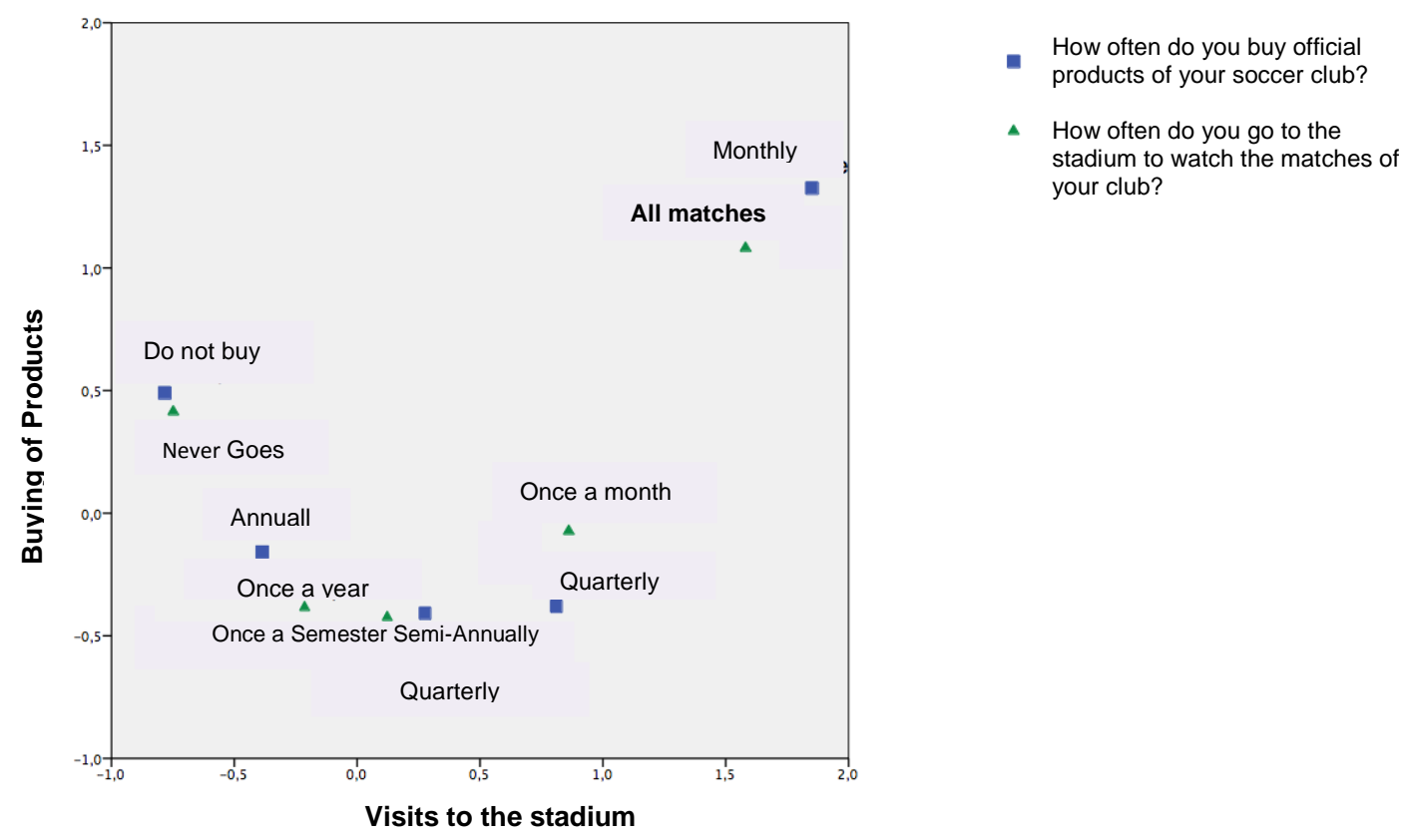

Graph 1: Association between frequency to the stadium and frequency of buying

Source: Research carried out by the authors

It is possible to identify, according to Gladden and Funk (2002) that the presence in the stadium is associated with the higher frequency of buying and justify the argument of Wert-Gray and Gray (2012) that larger impact on consumption takes place after the identification establishment between the club and supporter. The stadium shows up in this way, the structural foundation for working up the concept of loyalty raised by Bauer et al. (2008).

The result confirms the proposals of Bee and Kahle (2006), when they state that loyal supporters who go to the stadium more frequently are in the internalization stage. At this stage, they will be more likely to consume the official products of the club since they will seek to demonstrate their connection with the team using products that bring its brand. Those who do not go to the stadium (not a single time) are in the observing stage - in which there is no involvement.

\subsection{FREQUENCY OF VISITS TO THE STADIUM AND ANNUAL AVERAGE TICKET WITH EXPENDITURES IN OFFICIAL PRODUCT}


It can be observed in Table 2, that when a comparison is made between the frequency of going to the stadium and the supporters average annual expenditure with official products, that these variables are not independent $\left(\chi^{2}=\right.$ $286,878 ; p=0,000)$, in other words, they are not randomly combined, allowing the application of the correspondence analysis technique.

Table 2: Table of comparison between supporters' frequency of going to the stadium and annual expenditure with official products

\begin{tabular}{|c|c|c|c|c|c|c|}
\hline \multirow{4}{*}{$\begin{array}{l}\text { Frequency of } \\
\text { going to the } \\
\text { stadium }\end{array}$} & \multicolumn{6}{|c|}{ Supporters annual expenditure with official products } \\
\hline & \multicolumn{6}{|c|}{$\mathrm{R} \$ 150,01 \quad \mathrm{R} \$ 300,01$} \\
\hline & & Up to & to & to $R \$$ & Over & \\
\hline & Do not buy & $\mathrm{R} \$ 150,00$ & $\mathrm{R} \$ 300,00$ & 500,00 & $\mathrm{R} \$ 500$ & Total \\
\hline Never go & 157 & 90 & 87 & 32 & 1 & 367 \\
\hline Once a year & 52 & 65 & 80 & 31 & 4 & 232 \\
\hline $\begin{array}{l}\text { Once a } \\
\text { semester }\end{array}$ & 27 & 30 & 63 & 22 & 7 & 149 \\
\hline $\begin{array}{l}\text { Once a } \\
\text { quarter }\end{array}$ & 24 & 25 & 72 & 38 & 17 & 176 \\
\hline Once a month & 17 & 25 & 85 & 42 & 31 & 200 \\
\hline All matches & 3 & 9 & 19 & 24 & 22 & 77 \\
\hline Total & 280 & 244 & 406 & 189 & 82 & 1201 \\
\hline$\chi^{2}: 286,878$ & GL:20 & $p: 0,000$ & & & & \\
\hline
\end{tabular}

In Graph 2, it can be observed the association between the frequency of going to the stadium and the supporter annual average ticket. In this case, it was found that the highest average ticket of the research (over \$500) is strongly associated to the supporters who always go to the stadium. While the consumers who said they do not buy official items of their clubs are associated with those who said they do not go to the stadium. This result is in line with the theory presented (Gladden \& Funk, 2001; Gray \& Wert-Gray, 2012). 


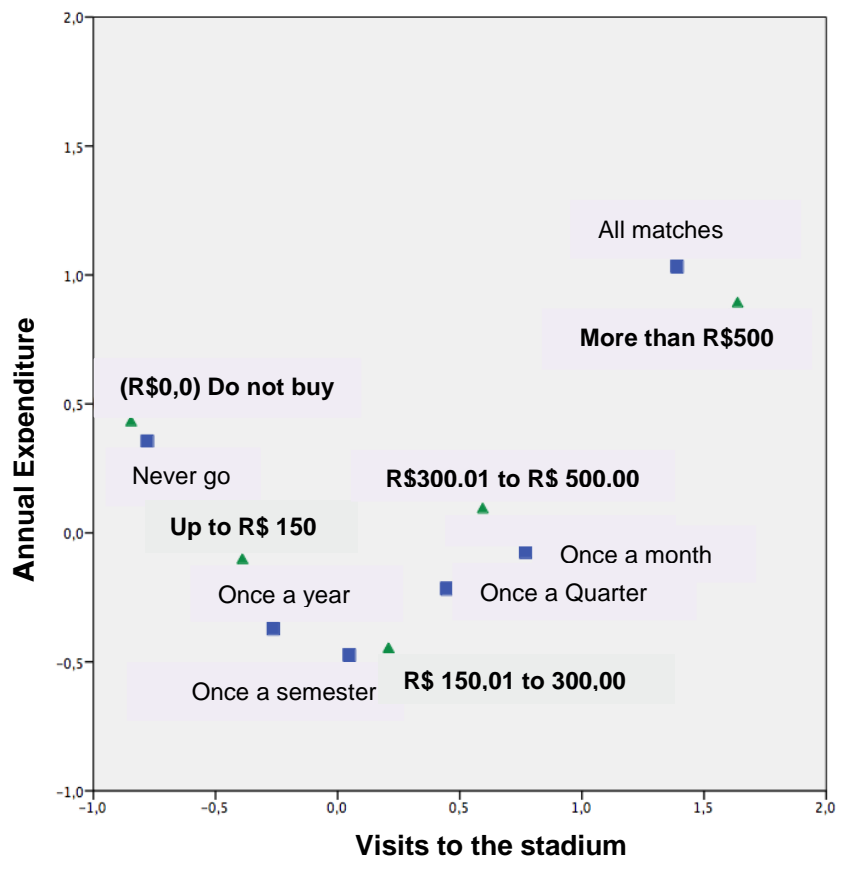

How often do you go to the stadium to watch matches of your club?

How much do you spend annually buying official products of your club?

\section{Graph 2: Comparison between supporter's frequency of going to the stadium and annual expenditure with official products}

Source: Research carried out by the authors

The proposed by Bee and Kahle (2006), who state there is the need for retaining the consumer proves accurate when identifying that the supporters who have the habit of going to the stadium are those that have higher average ticket and more frequently buy official products. When the supporter assumes a relationship with the club, going to the stadium much more frequently, and this fact influences on the average ticket as well as the frequency of official products buying, than we can transpose to the soccer supporter the thought of Wulf and Odekerken -Schroder (2003), which propose a relation between the relationship commitment and their behavioral loyalty.

In the data analysis, it is suggested that there is a positive relationship between the average ticket and the supporter average income. Among those who earn a household income above 20 minimum wages, 17.9\% reported spending more than $\mathrm{R} \$ 500.00$ a year in their club, while the average reported by other levels of income drops to $6.6 \%$. In the sample, it is reflected a natural relationship of the consumer market and it demonstrates to the clubs that there are people willing to consume more expensive products that show higher added value. A real example of this new demand is the premium box seats at Morumbi 
stadium, sponsored by Visa company, the unit costing $\mathrm{R} \$ 160.00$ per match and the special chairs at any match of Corinthians in the Libertadores Championship, reached the cost $R \$ 600.00$ each in 2012. Thus, as stated by Wert-Gray and Gray (2012), the results of a work well developed outside the soccer pitch can bring extremely positive results for clubs.

\subsection{FREQUENCY OF GOING TO THE STADIUM AND THE ASSORTMENT OF PURCHASED PRODUCTS}

Table 3 shows the comparison between the frequency of going to the stadium and the assortment of purchased products by supporters. It is possible to verify that these variables are not independent $\left(\chi^{2}=163,389 ; p=0,000\right)$, in other words, they do not combine randomly, which allows the application of the correspondence analysis technique.

Table 3: Table of comparison between the frequency of going to the stadium and the assortment of purchased products

\begin{tabular}{lccccc}
\hline & \multicolumn{5}{c}{ Assortment of purchased products } \\
\cline { 2 - 6 } $\begin{array}{l}\text { Frequency of going } \\
\text { to the stadium }\end{array}$ & $\begin{array}{c}\text { From one to } \\
\text { four }\end{array}$ & $\begin{array}{c}\text { From five } \\
\text { to eight } \\
\text { products }\end{array}$ & $\begin{array}{c}\text { Above nine } \\
\text { products }\end{array}$ & products & Total \\
\hline Never go & 157 & 187 & 20 & 3 & 367 \\
\hline Once a year & 52 & 152 & 27 & 1 & 232 \\
\hline Once a semester & 27 & 92 & 28 & 2 & 149 \\
Once a quarter & 24 & 127 & 18 & 7 & 176 \\
Once a month & 17 & 152 & 29 & 2 & 200 \\
\hline All matches & 3 & 53 & 16 & 5 & 77 \\
\hline Total & 280 & 763 & 138 & 20 & 1201 \\
\hline
\end{tabular}

$\chi^{2}: 163,389 \quad \mathrm{GL}: 15 \quad \mathrm{p}: 0,000$

The results show an association between higher frequency of going to the stadium and assortment of products purchased (Graph 3). Thus, the higher the frequency to the stadium, the higher the mix of products purchased by supporters. Items most frequently mentioned by the respondents who buy more 
than five products include flags, caps, keyrings and mascots. Referring to the clubs shirts and uniforms they are products that are part of all supporters portfolio, in other words, those who go to the stadium few times give preference to their team uniform to another type of product. It is still observed in Graph 3, that the non purchase of products strongly corresponds to respondents who do not go to the stadium.

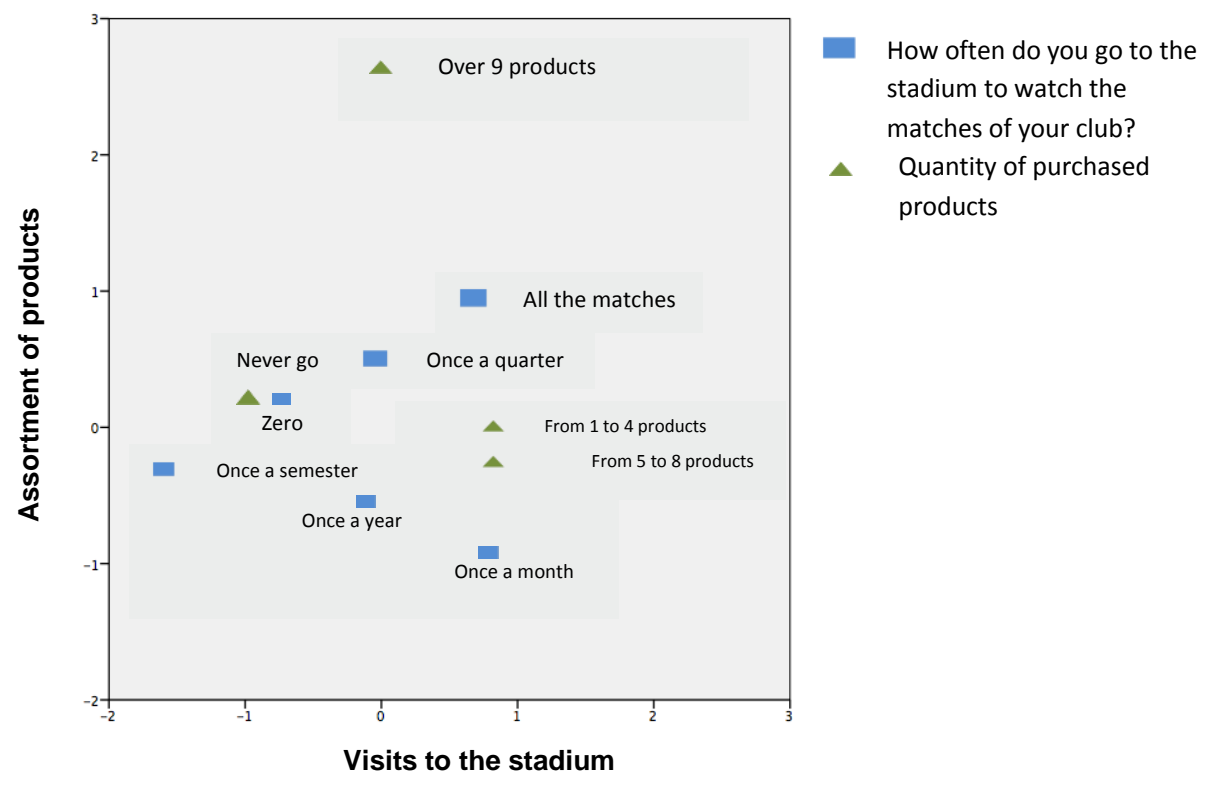

\section{Graph 3: Association between the frequency of going to the stadium and the assortment of purchased products}

Source: Research carried out by the authors

In the result of the association between going to the stadium and assortment of products purchased it is corroborated the earlier results of this study and the proposals of Bee and Kahle (2006) referring to the supporters internalization. At this stage supporters show interest in acquiring products of their clubs, in the most varied ways. Referring to the supporters who go to the stadium less frequently they prefer to show their taste exclusively consuming their team uniform.

The largest assortment of products can not only provide new revenues to clubs, but also achieve a new consumer audience. This diversification of products has already been occurring in official club stores, where today it is possible to find many products with the team logo, but that are not directly related to soccer. 


\subsection{IMPACTING FACTORS IN THE CONSUMER LOYALTY}

Another important issue for the brand management in sport and, especially in soccer, is the factor that may impact the relation between loyalty, measured by the frequency of the supporter going to the stadium and his purchase frequency and average ticket. In the results, it is noticed that the price was identified as a common complaint among the supporters, being the main reason for complaint for both, those who purchase (71\%), and for those who do not purchase (54\%) official products, which corroborates what was pointed out by Kapferer (2003). Thus, when analyzing that consumers would prefer to purchase their club official uniforms and shirts, of a value very close to the average ticket presented at the sample result, it can be inferred that, in making a decision between increasing the number of products purchased from their club and buying an official shirt, the supporter will prefer the shirt.

To increase the consumption average ticket, clubs should not just think about a strategy based on increasing the product portfolio. It is important to consider pricing strategies that will convince consumers to buy new products that take their club brand name, because, among those who buy the club products, it is interesting to notice that, after the price, the major complaints are in relation to the product attractiveness (20\%) and its usefulness (23\%) (Graph 4 ). This indicates that the consumer expects their club offer them products more suited to their needs. 


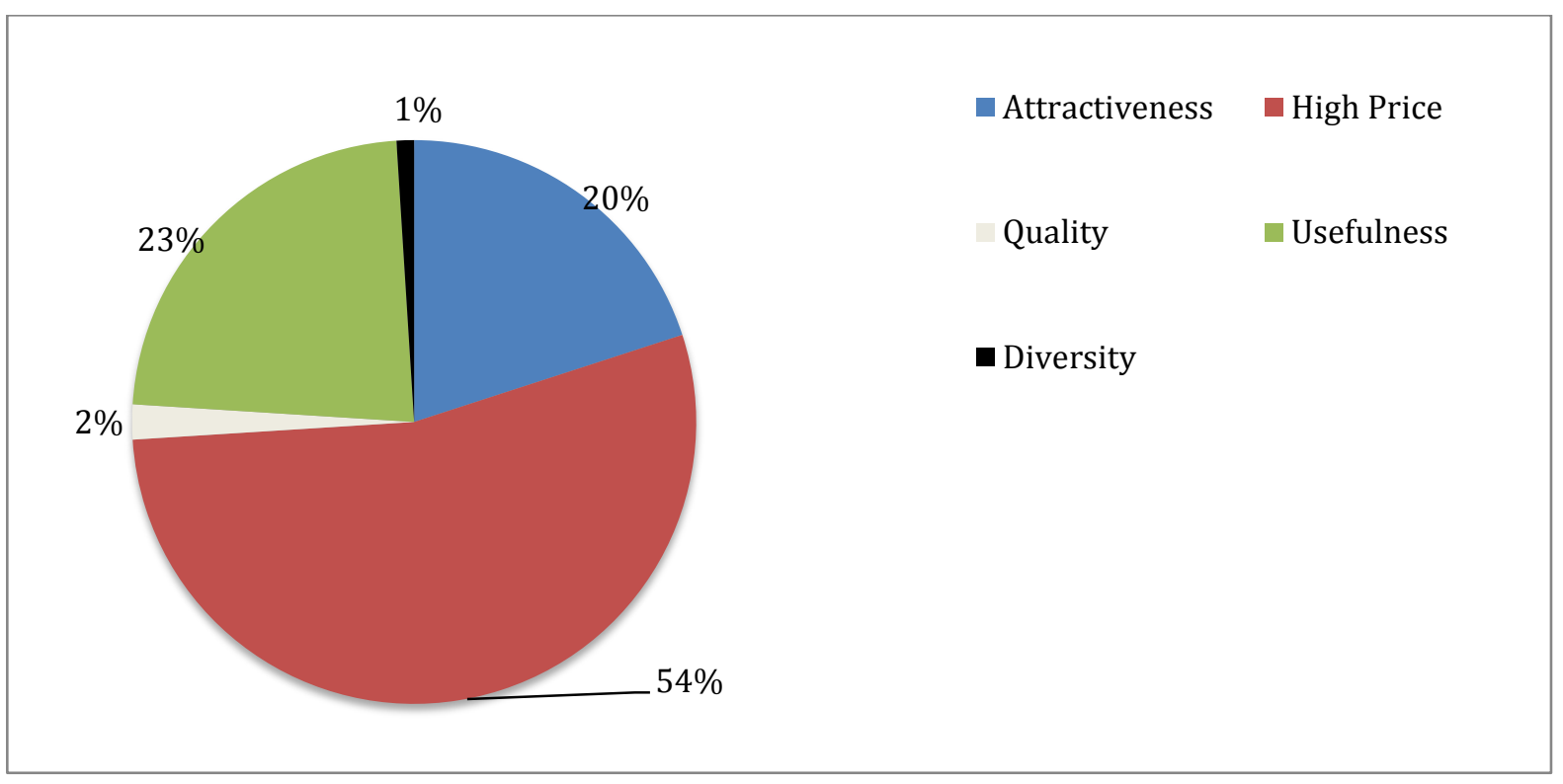

\section{Graph 4: Factors that limit the official products purchase}

Source: Research carried out by the authors

At this point, the adequacy of the brand architecture (Aaker \& Joachimsthaler, 2000), shows to be essential because it enables the clubs to have different prices for each target segment. Making use of sub-brands or endorsed brands, clubs can expand the products and services offered to their several groups of stakeholders. The expansion of the product portfolio is necessary, but in order to avoid cannibalization between the products themselves, it is important to analyze the association of brands that help strengthen the club's brand in the market.

Keyrings, balls and flags are gone for this kind of consumer who wants to identify himself with the club through products that can actually be worn. Among both, those who buy and those who do not buy the official products, the quality is not an item that presents concern, which helps to understand the answer to one of the questions that can better strengthen the idea of the clubs projecting themselves in the market as a brand - the consumer is likely to buy the club products in relation to the more traditional brands according to data collected in this study (Graph 5). 


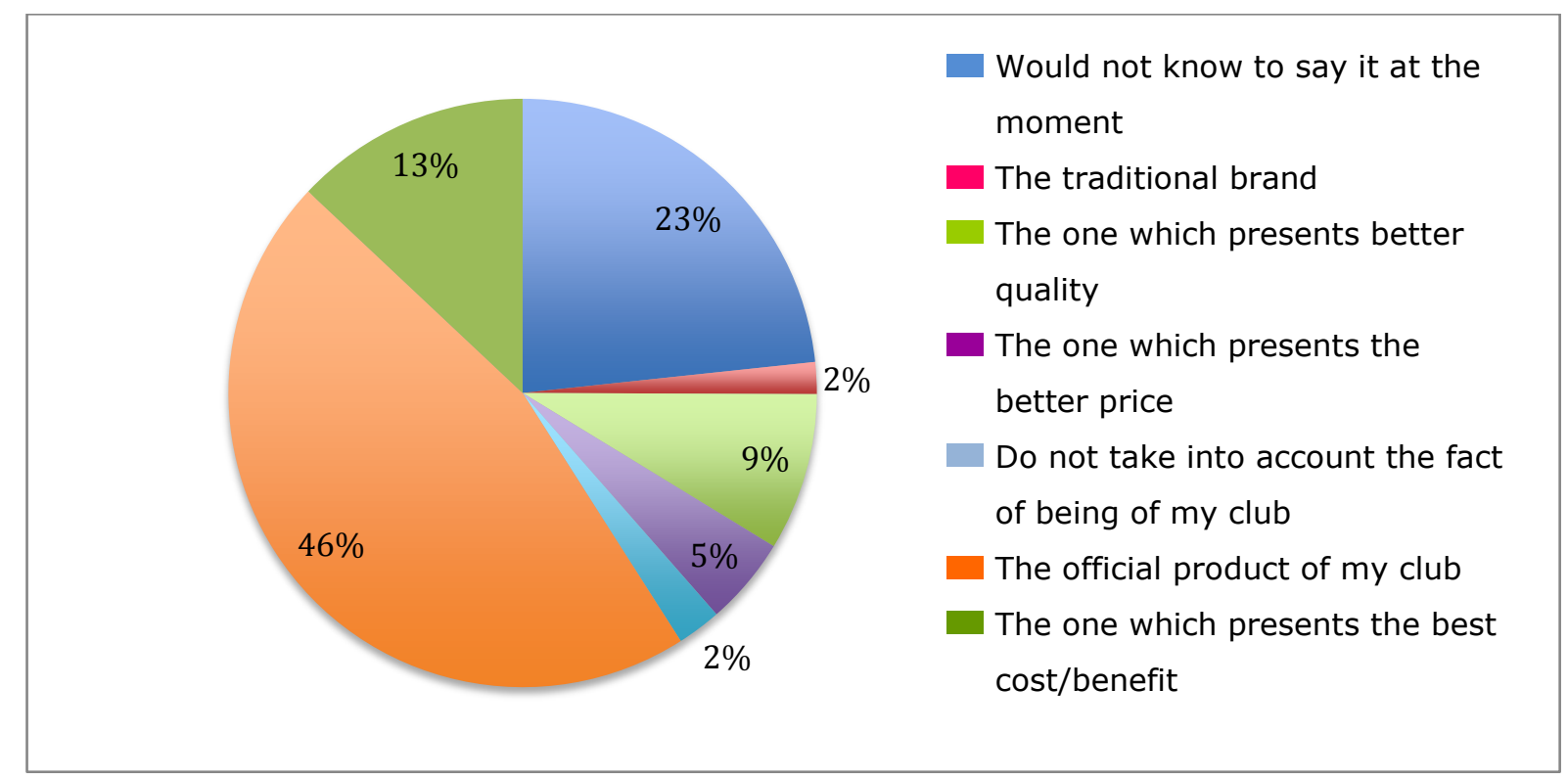

\section{Graph 5: Consumer choice for the club products or for well known brands products}

Source: Research carried out by the authors

\section{DISCUSSION}

The research points out that the Brazilian soccer supporters are, in general, in the second stage indicated by Bee and Kahle (2006), the identification phase, in which more consumption can be expected, as long as there is improvement in the relationship between clubs and their consumers. However, it is important that clubs work their marketing to lead the supporters to what the authors called the third stage, the internalization, when the sharing of values is in the foreground. In this process, the stadium can be a major differential for this movement.

The relationship marketing can and must be used to attract, develop and retain the consumer (Bee $\&$ Kahle, 2006). It is therefore important that the soccer clubs start to see their supporters also as consumers, not just as spectators. Analyzing the Brazilian soccer clubs marketing actions (Malagrino, 2011), it is noted an intense work of the marketing departments in the pursuit of 
innovative solutions capable of attracting the supporters and turn them into consumers, improving the relationship club/supporter within one of the groups (those who go to the stadium) proposed by Tokuyama and Greenwell (2011). The benefit is the improvement of the clubs revenues and their brand valuation (Malagrino et al., 2012).

If investigated, the Flamengo soccer club case, which has around 32 million supporters (Pluri, 2013) and applying the average ticket as the lowest amount of the average indicated by the research $(R \$ 150,00)$, it is possible to project an estimate of revenues. In case it reaches $5 \%$ of their supporters (1.6 million), the club could raise, only through direct sale for their supporters, about $\mathrm{R} \$ 240$ million per year - an amount higher than the club total revenue in 2012, $\mathrm{R} \$ 185$ million (BDO, 2012). If the same is applied to all the soccer clubs listed in this paper, it will present similar data, evidencing the supporter importance in the formation of the revenue of Brazilian clubs.

However, when international surveys are analyzed and compared the values of the major international soccer clubs brands (Forbes, 2012), it is evident that the path Brazilian clubs have to go through is still a long one. The sum of the 12 most valuable brands in the Brazilian soccer - $R \$ 5$ billion (BDO, 2012) - is slightly above the value of the most valuable brand in the soccer world, Manchester United - R\$ 4,02 billion (US\$ 2.35 billion); Real Madrid and Barcelona complete the trio of soccer clubs with the most valuable brand, $\mathrm{R} \$$ 3,37 billion (US\$ 1.87 billion) and R\$2,35 billion (US\$ 1.30 billion) (Forbes, 2012). This brand valuation on the part of supporters, through the increase of buying official products, displays the possibility of working the customer loyalty, an important factor for the clubs according to Gladden and Funk (2001).

To the clubs, understanding these associations permits the definition of relationship marketing strategies more aligned with the specificities of different supporters groups, aimed at the revenue maximization by selling products and services to them. Besides the official products such as the uniforms, clubs have expanded the range of services offered to their supporters, such as loyalty programs, website and social networks, exclusive TV channels and travel agencies. However it is worth noting that the relationship marketing according to Bee and Kahle (2006), benefits from sound management of database about the buying behavior of consumers/supporters. 


\section{FINAL CONSIDERATIONS}

In the search for a long-term relationship, clubs need to reduce the consumer choice options (Parvatiyar \& Sheth, 2001), offering them products more attractive and more consistent with their actual needs. In building this long-term relationship, the stadium might assume an important role (Malagrino, 2011). As shown in the survey, supporters who have more engagement with the club are those who tend to consume more frequently with higher average ticket and a wider range of products.

If the consumer of sports products is, in general, involved with their clubs (Bee \& Kahle, 2006), the frequency of going to the stadium can become a differential in the relationship, increasing confidence of consumers/supporters regarding their team and even sharing essential values in this relationship maintenance. The stadium can then become one of the most effective means of relationship for the soccer clubs as it is the place where the club has a chance to give the consumer the unique experience of cheering. This concept can be a key player to increase both, the presence of the public, as well as the club billing, not only because of ticket office itself, but mainly because of the involvement of the supporter/consumer with the club, as pointed out in the survey.

It is necessary that the clubs see the supporter not only as consumers in this show called soccer. It is important to identify the supporter as the event producer, at the same time he is the receiver of the action he seeks a more active participation in the show that he helps create. The clubs need to develop in the supporter not only his role of consumer, but also to be the producer of the show - the one who appreciates the clubs actions inside the stadium - helping in this way to improve the relationship between the parties. For this, the construction of hospitality mechanisms (Bee \& Kahle, 2006) becomes more than necessary.

Thus, the supporter assumes a dual role in the relationship with his club. At the same time that he is the actions target audience of the relationship marketing, he is also the foundation that helps to enhance the spectacle. At this point, the sport appears to be cruel to one of their main agents, because the more the supporter keeps his relationship with the club, the more he adds value to the spectacle and, consequently, the more expensive this relationship will 
become for him (Malagrino, 2011). But clubs should be alert and cannot believe that, despite the supporter high fidelity, he will never be unfaithful; it is not being considered here the supporter migration to other national clubs, but the customers' migration to other brands. As it is alerted by Kapferer (2003), consumers may become unfaithful when they judge that the price brand is higher than the value he had predicted.

\subsection{LIMITATIONS AND FUTURE STUDIES}

In this research it was also found some limitations that must be pointed out. Although the sample is considered ample for the analysis purpose, the choice of the snowball technique and the use of Twitter and Facebook to spread the research, although advantageous in the matter of the response time and scope, it produced some effects that limit the research. The disadvantage of this technique is that the responses were given far away from the moment the consumer could live the experience of cheering: the stadium. Furthermore, they do not follow a probabilistic distribution and cannot be generalized for the whole country. In this item, it is important to insert an even larger exception, since, considering the number of supporters of Sao Paulo clubs who responded the survey, it becomes clear that the authors' network of relationships influenced the number of consolidated responses. It must be emphasized that, despite the demonstration of the researchers' network contacts interference, the results cannot be dismissed, on the contrary, they justify the importance of this first study and point towards issues to be explored in future studies.

Despite the developments of the sports industry in Brazil, especially soccer, the national academic scene is still lagged behind the international market. At this point, this work does not intend to point out either irrefutable proofs or unique solutions, but rather serve as an example so that new models can be proposed and presented not only within the academic sphere but also for soccer clubs. Thus, this research aims to contribute to a greater understanding of the relationship marketing effect on the soccer supporter and the brand loyalty of the soccer clubs in Brazil. It was sought to serve as a basis for further research that wish to improve brand management, licensing and commercialization of products by the Brazilian soccer clubs and also to inspire the professionals involved with 
the clubs to seek, in the marketing field and academic studies, the tools to leverage the soccer business in our country.

Through the research carried out, it is evident that the path on which our sports industry walks, driven by hosting of two of the world's biggest mega events (World Cup and Olympic Games), puts Brazil as the focus of studies in the coming years, within this new scenario. It is believed that the management area and its professionals will have high relevance in this new scenario. It is enough to notice the number of international companies that are coming to Brazil and the values that should be invested in our market in the next five years: US $\$ 100$ billion (Estadão, 2011).

This research has aroused in the own authors and it is expected that it also has aroused in the other researchers, the need to open new areas of investigation in relation to Brazilian sport management as a whole. The hosting of the World Cup and the construction or renovation of 12 stadiums that hosted the event is an important area to be investigated in the coming years. How to transform these stadiums in multipurpose arenas, attract more consumers and turn them into profitable businesses are some of the challenges to be worked by professional of the soccer clubs in Brazil, as these challenges will have direct impact on the clubs revenues and will become part of the day to day of the marketing professionals. The so called matchday, which, in the European Championships, represents $25 \%$ of the leading clubs revenues (Forbes, 2012) and that is directly related to the frequency of going to the stadium and to the supporter consumption during the match, needs to be incorporated to shopping cart revenues of Brazilian clubs.

Following the marketing actions development and their impact on the Brazilian soccer supporters is also an important area to be investigated by the academic scholars as well as whether the clubs have been working towards turning themselves into big brands and explore new markets. In this sense, research on competition between the soccer brands and other brands of international soccer and/or consumer branding are interesting areas to be studied, since they raise the questioning of whether the domestic clubs supporters are faithful or not to the brands when consuming brands of international clubs, or even other brands in fashion whose products portfolio are in conflict with theirs. 
Other challenges that can and should be studied by future academic researchers are associated with the marketing of services and with the introduction of new social media as a communication platform of the clubs, athletes and sponsors with their supporters/consumers. Within the relationship marketing it will be important to research the introduction of the loyalty programs (CRM) of the national clubs and understand the relationship between the performance on the soccer pitch and the revenue generated by the consumers.

\section{REFERENCES}

Aaker, D., \& Joachimsthaler, E. (2000). Como construir marcas líderes. São Paulo: Futura.

Batista, L., Escuder, M., \& Pereira, J. (2004). A cor da morte: causas de óbito segundo características de raça no estado de São Paulo, 1999 a 2001. Revista de Saúde Pública, 38(5), 630-636.

Bauer, H. H., Stokburger-Sauer, N. E., \& Exler, S. (2008). Brand image and fan loyalty in professional team sport: A refined model and empirical assessment. Journal of Sport Management, 22(2), 205-226.

BDO Auditores Independentes. (2012). Finanças dos clubes brasileiros e valor das marcas dos 17 clubes mais valiosos do Brasil. São Paulo.

Bee, C., \& Kahle, L. (2006). Relationship marketing in sports: A functional approach. Sports Marketing Quarterly, 15(2), 102-110.

Bendapudi, N., \& Berry, L. L. (1997). Customers' motivations for maintaining relationships with service providers. Journal of Retailing, 73(1), 1537.

Beting, E. (2011, julho). Vai chover dinheiro: Entenda como o novo acordo para a transmissão teve impacto direto nas receitas dos clubes e deve turbinar seu time no meio do ano. Revista Placar, edição n. 1356. p. 26.

Chao, L. (2013). Corinthians reflete a ascensão da classe média brasileira. The Wall Street Journal, Recuperado em 05 de julho, 2014 de http://online.wsj.com/news/articles/SB100014241278873236964045783007034 28422438?tesla=y\&tesla $=y$ 
Dawes, J. (2009). Brand loyalty in the UK sportswear market. International Journal of Market Research, 51(4), 449-463.

Ehrenberg, A. (1991). Politicians' double jeopardy: a pattern and exceptions. Journal of the Market Research Society, 33(1),347-353.

Ehrenberg, A. (2000). Repeat-buying: facts, theory and applications. Journal of Empirical Generalisations in Marketing Science, 5, 392-770.

Ehrenberg, A., \& Goodhardt, G. (2002). Double jeopardy revisited, again. Marketing Insights, Marketing Research, 14(4), 40-42.

Estadão. (2011). Esporte vai movimentar mais de $\mathrm{R} \$ 100$ bi no país. Mundial de futebol e Olimpíadas fazem do Brasil nova meca para a indústria esportiva e empresas do setor. Recuperado em 10 de outubro, 2012, de http://www.estadao.com.br/noticias/impresso,esporte-vai-movimentar-mais-der-100-bi-no-pais-, 786821,0.htm

Favero, L. P. L, Belfiore, P. P., Chan, B. L., \& Silva, F. L da S. (2009). Análise de dado: modelagem multivariada para tomada de decisões. Rio de Janeiro: Elsevier.

Forbes. (2012). The world's most valuable soccer teams. Recuperado 18 de setembro, 2012, de http://www.forbes.com/2011/04/20/worlds-mostvaluable-soccer-teams_slide.html

Freitas, H., Oliveira, M., Saccol, A., \& Mascarola, J. (2000, julhosetembro). Método de pesquisa survey. Revista de Administração da Universidade de São Paulo - Rausp, 35(3), 105-112.

Gladden, J. M., \& Funk, D. C. (2001). Understanding brand loyalty in professional sport: Examining the link between brand associations and brand loyalty. International Journal of Sports Marketing and Sponsorship, 3(1), 67-94.

Gladden, J. M., \& Funk, D. C. (2002). Developing an understanding of brand associations in team sport: Empirical evidence from consumers of professional sport. Journal of Sport Management, 16(1), 54-81.

Gray, G. T., \& Wert-Gray, S. (2012). Customer retention in sports organization marketing: Examining the impact of team identification and satisfaction with team performance. International Journal of Consumer Studies, 36(3), 275-281.

Kapferer, J. (2003). As marcas, capital da empresa: Criar e desenvolver marcas fortes. Porto Alegre: Bookman. 
Kaynak, E., Salman, G. G., \& Tatoglu, E. (2008). An integrative framework linking brand associations and brand loyalty in professional sports. Journal of Brand Management, 15(5), 336-357.

Lings, I., \& Owen, K. (2007). Buying a sponsor's brand: The role of affective commitment to the sponsored team. Journal of Marketing Management, 23(5/6), 483-496.

Malagrino, F. de A. F. (2011). Gestão das marcas dos clubes de futebol: Como o marketing esportivo potencializa o consumo do torcedor. Dissertação de Mestrado, Pontifícia Universidade Católica de São Paulo, São Paulo, SP, Brasil.

Malagrino, F. de A. F, Vance, P., Cardoso, M. V., \& Silva, E. (2012, January). Changing the rules of the game: $B 2 B$ alliances in Brazilian sports teams. Apresentação Sessão B2B Sponsorship no 18th CBIM Academic Workshop, Atlanta, Georgia, Estados Unidos.

O'Brien, L., \& Jones, C. (1995, May-June). Do rewards really create loyalty? Harvard Business Review, 73(3), 75-82.

Parvatiyar, A., \& Sheth, J. (2001). The domain and conceptual foundations of relationship marketing. In J. N. Sheth, \& A. Parvatiyar (Eds.), Handbook of relationship marketing (pp. 3-38). Thousand Oaks, CA: Sage.

Pereira, J. (1997). Análise de dados qualitativos. São Paulo: Edusp.

Pestana, M. H., \& Gageiro, J. N. (2000). Análise de dados para ciências sociais: A complementaridade do SPSS (2a ed.). Lisboa: Silabo.

Pluri Consultoria. (2012). O PIB do Esporte Brasileiro.

Pluri Consultoria. (2013). $1^{a}$ Pesquisa PLURI STOCHOS Tamanho de Torcidas.

Ross, S. (2006). A conceptual framework for understanding spectatorbased brand equity. Journal of Sport Management, 20(1), 22-38.

Shamir, B., \& Ruskin, H. (1984). Sport participation vs. sport spectatorship: Two modes of leisure behavior. Journal of Leisure Research, $1(26), 9-21$.

Sheth, J. N., \& Parvatiyar, A. (1995). Relationship marketing in consumer markets: Antecedents and consequences. Journal of the Academy of Marketing Science, 23(4), 255-271.

Severino, A. (2007). Metodologia do trabalho científico. São Paulo: Cortez. 
Stavros, C., Pope, N. K. L., \& Winzar, H. (2008). Relationship marketing in Australian professional sport: An extension of the Shani framework. Sport Marketing Quarterly, 17(3), 135-145.

Stone, G. P. (1971). American sports: Play and display. In E. Dunning (Ed.), The sociology of sport (pp. 47-65). London: Frank Cass-Co.

Stum, D. L., \& Thiry, A. (1991, April). Building customer loyalty. Training and Development Journal, 45(3), 34-36.

Tokuyama, S., \& Greenwell, T. (2011). Examining similarities and differences in consumer motivation for playing and watching soccer. Sports Marketing Quarterly, 20(3), 148-156.

Whitlark, D. B., \& Smith, S. M. (2001). Using correspondence analysis to map relationships. Marketing Research, 13(3), 22-27.

Wulf, K., \& Odekerken-Schroder, G. (2003, March). Assessing the impact of a retailer's relationship efforts on consumers' attitudes and behavior. Journal of Retailing and Consumer Services, 10(2), 95-108. 